\section{Urgência na introdução do NAT: é fundamental não cometer os erros do passado}

\section{Urgency of the introduction of NAT: it is crucial not to commit past errors}

\author{
Carlos S. Chiattone ${ }^{1}$ \\ João Pedro M. Pereira ${ }^{2}$ \\ Dante M. Langhi Junior ${ }^{3}$ \\ Marilia A. Rugani ${ }^{4}$ \\ Carmino A. de Souza ${ }^{5}$ \\ João Carlos P. Saraiva ${ }^{6}$ \\ Sergio Mesiano
}

'Presidente da $\mathrm{SBHH}$

${ }^{2}$ Vice-Presidente da $\mathrm{SBHH}$

${ }^{3}$ Diretor Administrativo da $\mathrm{SBHH}$

${ }^{4}$ Diretora Financeira da SBHH

${ }^{5}$ Professor. Diretor Científico da SBHH

${ }^{6}$ Hemoterapeuta e patologista clínico. Diretor de Comunicação da SBHH

${ }^{7}$ Hematologista. Diretor de Defesa de Classe da SBHH

\section{Senhor Editor}

Em seu editorial "Urgência na introdução do NAT: é fundamental não cometer os erros do passado"1, a diretoria da Sociedade Brasileira de Hematologia e Hemoterapia (SBHH) fez um alerta sobre a importância da utilização dos testes NAT na triagem do sangue doado no Brasil como mais uma medida para aumentar a segurança da transfusão e que não podemos prescindir de procedimentos técnicos disponíveis que aumentem a segurança da transfusão por razões de "caráter econômico".

A utilização dos testes NAT para HIV, HCV e HBV reduz de maneira significativa o risco residual dessas infecções para os receptores de transfusão. ${ }^{2,3}$

$\mathrm{O}$ assunto "segurança da transfusão" é sem dúvida amplo e abrangente e discuti-lo como um todo não foi o objetivo do Editorial. ${ }^{1}$ Discussão ampla sobre o tema teve como fórum importante o último Congresso da SBHH - Hemo 2008 - onde o assunto foi ampla e exaustivamente discutido, com a presença de profissionais do Brasil e de diversas partes do mundo. O Hemo é hoje o quarto maior congresso da especialidade no mundo e nessa última edição foi considerado, por profissionais de outros países, como um dos melhores congressos do mundo em hematologia e hemoterapia. Isso deixa claro o empenho, seriedade e dedicação das últimas diretorias da SBHH na busca do desenvolvimento da hematologia e hemoterapia no Brasil.

O estímulo ao doador de sangue "mais seguro" sempre foi preocupação da $\mathrm{SBHH}$, haja vista, entre outras inúmeras condutas, ter sido a grande defensora da extinção da doação remunerada no País, capitaneando campanha com esse objetivo durante o início dos anos 1980, que culminou com a proibição desse tipo de doação no Brasil. Desconhecemos fato mais importante no que se refere ao estímulo ao "doador de sangue mais seguro" no Brasil.

Wendel e cols. fazem referência à importância das "boas práticas laboratoriais" e que em alguns locais do País o desempenho da testagem sorológica ainda está aquém do desejado, conforme "relatórios da Anvisa". Não encontramos no texto qualquer referência bibliográfica que documente essa afirmação sobre os "relatórios da Anvisa".

O programa de "Controle de Qualidade Externo em Sorologia", da SBHH, utilizado pela maioria quase absoluta dos serviços que realizam triagem laboratorial do sangue doado, tem demonstrado desempenho bastante satisfatórios dos participantes, deixando claro as "boas práticas" desses serviços. Exceções não podem ser vistas como regra.

Com relação ao uso de testes sorológicos combinados para detecção de antígeno e anticorpo, como alternativa à implantação dos testes NAT, estudos demonstraram diminuição do período de janela sorológica para o vírus HIV de aproximadamente quatro dias, ${ }^{4}$ e para o vírus $\mathrm{HCV}$ em torno de 26 dias, ${ }^{5}$ favorecendo o uso desses testes em locais onde os testes NAT não podem ser realizados, porém não como substitutos destes.

Esses testes combinados apresentam custos inferiores aos testes NAT, porém significativamente superiores aos testes Elisa para detecção de anticorpo isoladamente, e apresentam diminuição da janela imunológica ainda bem inferior aos testes NAT.

Os testes combinados apresentam limitações, como a possibilidade de resultados falso-negativos devido à "segunda fase de janela diagnóstica". Esse problema pode ocorrer em casos de infecção inicial por HIV e HCV quando existe diminuição dos níveis de antígenos e anticorpos da classe IgG ainda não são detectados., ${ }^{5,6,7}$

Com relação à utilização de testes de biologia molecular por plataformas caseiras (in house), a legislação brasileira que normatiza a prática hemoterápica no País, ${ }^{8} \mathrm{em}$ seu item E.2.1., obriga que a triagem do sangue coletado deva ser realizada utilizando conjuntos diagnósticos registrados na Anvisa. Nós não somos contrários ao desenvolvimento de novas metodologias, porém quaisquer que sejam essas metodologias, somente poderão ser utilizadas na prática hemoterápica após registro na Anvisa. A diretoria da SBHH entende que a utilização de conjuntos diagnósticos não registrados na Anvisa contraria a lei e não pode ser praticada, estando os que a utilizam sujeitos às sanções penais. É importante ainda esclarecer que o processo de registro de produtos para utilização na área da saúde contempla diversas etapas de avaliação, para garantir que os produtos apresentem o desempenho desejado. A utilização de produtos não registrados, além de ilegal, deixa dúvidas sobre a sua qualidade, o que não pode em hipótese alguma ocorrer quando se trata da segurança da transfusão. 


\section{Abstract}

This letter to the Editor about "the urgency of the introduction of NAT in Brazil" complements and defines the position of the Directorate of the Brazilian Society of Hematology and Hemotherapy in respect to letters to the Editor both in this and the previous issue of the RBHH. Rev. Bras. Hematol. Hemoter. 2009;31(2):113-114.

Key word: Nat.

\section{Referências Bibliográficas}

1. Chiattone CS, Marques Pereira JP, Langhi Jr. DM, Rugani MA, Souza CA, Saraiva JCP, Mesiano SB. Urgência na introdução do NAT: é fundamental não cometer os erros do passado. Rev. Bras. Hematol. Hemoter. 2008;30(04):259.

2. Stramer SL, Glynn AS, Kleinman SH, Strong DM, Caglioti S, Wright DJ, et al. Detection of HIV-1 and HCV infections among antibodynegative blood donors by nucleic acid-amplification testing. $\mathrm{N}$ Engl J Med. 2004;351:760-8.

3. Lapercche S. Blood safety and nucleic acid testing in Europe. Euro Surveill 2005;10:3-4.

4. Sickinger E, Jonas G, Yem AW, Goller A, Stieler M, Brennan C, et al. Performance evaluation of the new fully automated human immunodeficiency virus antigen-antibody combination assay designed for blood screening. Transfusion. 2008;48:584-593.

5. Laperche S, Elghouzzi MH, Morel P, Asso-Bonnet M, Le Marrec N, Giraut A, et al. Is an assay for simultaneous detection of hepatitis $\mathrm{C}$ virus core antigen and antibody a valuable alternative to nucleic acid testing? Transfusion. 2005;45:1965-72.

6. Meier T, Knoll E, Henkes M, Enders G, Braun R. Evidence for a diagnostic window in fourth generation assays for HIV. J Clin Virol. 2001;23:113-6.

7. Lanbert N, Prigent V, Slizewicz B, Gadelle S, Sanjuan A. Antibody performance remains essential for early detection in HCV antigenantibody assays. Vox Sang. 2007;93 Suppl 1:129-8.

8. Brasil. Ministério da Saúde. Anvisa - Agência Nacional de Vigilância Sanitária. RDC n ${ }^{\circ}$ 153, de 14 de junho de 2004 - Determina o Regulamento Técnico para os procedimentos hemoterápicos, incluindo a coleta, o processamento, a testagem, o armazenamento, o transporte, o controle de qualidade e o uso humano de sangue e seus componentes, obtidos do sangue venoso, do cordão umbilical, da placenta e da medula óssea. [on line] Brasília, DF: Anvisa; 2004.

Recebido: $29 / 10 / 2008$

Aceito: 08/12/2008

Sociedade Brasileira de Hematologia e Hemoterapia

Correspondência: Dante Mário Langhi Jr.

Rua Sergipe 634, Ap. 14

01243-000 - São Paulo-SP - Brasil

Fone: (55 11) 9962-6445 /Fax: (55 11) 3662-4050

E-mails:dlanghi@uol.com.br

hemoterapia@santacasasp.org.br 